\title{
Size-frequency estimates of secondary production by Mysis relicta in Lakes Michigan and Huron
}

\author{
Daniel W. Sell \\ Great Lakes Research Division, University of Michigan, Ann Arbor, MI 48109, U.S.A.
}

Keywords: Mysidacea, secondary production, size-frequency, biomass, Great Lakes

\begin{abstract}
Data from five Great Lakes studies of Mysis relicta populations were reanalyzed to calculate secondary production estimates using the size-frequency method. Production estimates $(P)$ ranged from 0.25 to $3.2 \mathrm{gdry}$ weight $\mathrm{m}^{-2} \mathrm{yr}^{-1}$. Average annual biomass $(\overline{\mathrm{B}})$ and mean annual density $(\overline{\mathrm{D}})$ were $0.11-1.11 \mathrm{~g} \mathrm{dry} \mathrm{weight} / \mathrm{m}^{2}$ and $25-434$ animals $/ \mathrm{m}^{2}$, respectively. $P: \bar{B}$ ratios varied only between 2.2 and 3.3. Maximum and minimum biomass values within a study varied by a factor of 519 for one study but by less than 17 for the others. Highest estimates of $P, \bar{B}$ and $\bar{D}$ were calculated for collections from a 50-m station in Lake Michigan despite the larger populations suspected to be present at greater depths sampled in the other studies. These conservative estimates provide a basis for scaling trophic interactions involving $M$. relicta and emphasize findings by previous workers that night-time sampling with vertical net hauls is the best available technique for quantitative studies of $M$. relicta populations in the Great Lakes.
\end{abstract}

\section{Introduction}

Mysis relicta is an important component of the food chain in the Great Lakes and in other northern lakes. The importance of Mysis in the diets of many Great Lakes fishes has been well documented (Wells \& Beeton 1963; Morsell \& Norden 1968; Foltz \& Norden 1977; Janssen \& Brandt 1980). Mysis has also been shown to be a voracious predator on zooplankton (Lasenby \& Langford 1972; Grossnickle 1978; Cooper \& Goldman 1980) and on Pontoporeia hoyi (Parker 1980). The introduction of $M$. relicta into lakes as prey for fish has been linked to dramatic alterations in zooplankton communities (Zyblut 1970; Northcote 1972; Richards et al. 1975; Morgan et al. 1978; Goldman et al. 1979). Furthermore, Mysis is capable of filter-feeding at high rates on colonial and single-celled phytoplankton (Grossnickle 1978) and has been shown to feed at night during summer stratification on phytoplankton in the deep chlorophyll maximum of Lake Michigan (Bowers \& Grossnickle 1978; Grossnickle 1979). Ferrante \& Parker (1978) suggest that Mysis has an important influence on silicon cycling in Lake Michigan as a result of its feeding on diatoms. Mysis may be a detritivore by day (Lasenby \& Langford 1972) or during periods of low plankton abundance (Grossnickle 1978). Knowledge of mysid production rates would aid understanding of the quantitative relationships between these dynamic processes.

Most methods for calculating secondary production of invertebrates require identifying and tracking cohorts. This is true for the removal-summation, increment-summation, instantaneous growth rate, and Allen curve methods (Waters 1977). The size-frequency method (Waters \& Hokenstrom 1980; Hynes 1980), formerly known as the Hynes or Hynes/Hamilton method (Hynes \& Coleman 1968; Hamilton 1969), does not require identifying cohorts. Size-frequency production estimates have been made for a variety of aquatic invertebrates 
including insects (Hynes \& Coleman 1968; Waters \& Crawford 1973; Benke 1976; Krueger \& Martin 1980), gastropods (Eckblad 1973), and amphipods (Martien \& Benke 1977; Welton 1979; Waters \& Hokenstrom 1980). The size-frequency method is an appropriate one for calculating secondary production of Mysis relicta in the Great Lakes because some reproduction within these populations occurs throughout the year and cohorts can not be easily followed (Morgan \& Beeton 1978). Size-frequency production estimates will be presented here for $M y$ sis relicta using five existing Great Lakes data sets. Furthermore, the conceptual framework for calculating production estimates will be used to compare density and biomasss data drawn from Great Lakes studies.

\section{Methods}

Unless otherwise indicated, measures of body length will be given as the distance from the tip of the rostrum to the tips of the telson. The lengthweight conversion used for all data except Morgan's (discussed below) was derived from Mysis relicta specimens collected at a $100-\mathrm{m}$ station in Lake Michigan west of Grand Haven, Michigan. Sampling was conducted on 7 November 1980 using a benthic sled during daylight hours and animals immediately preserved in $10 \%$ formalin. Animals were measured to the nearest $0.254 \mathrm{~mm}$ within 24 hours of collection for total body length and placed on aluminum foil boats. Specimens were then dried at $55^{\circ} \mathrm{C}$ for 48 hours in a drying oven, transferred to a desiccator containing silica gel, and weighed individually on a Cahn Electrobalance ${ }^{\circledR}$ Model 4400 . Dry weight was chosen, rather than wet weight, for use in production estimates discussed here because of inaccuracies due to evaporation while estimating wet weights of small invertebrates.

Menzie's (1980) formulation of the size-frequency method was used to calculate secondary production. This formulation incorporates both Benke's (1979) cohort production interval (CPI), which is a modification for voltinism, and Hamilton's (1969) correction for development times. Menzie (1980) suggests calculating numbers of individuals growing into size category $\mathrm{j}\left(\mathrm{N}_{\mathrm{j}}\right)$, here expressed in number $\mathrm{m}^{-2} \mathrm{yr}^{-1}$ :
$N_{j}=i \bar{n}_{j}\left(e_{j} / a_{j}\right)(1 / C P I)$

where $i$ is the number of size categories, $\bar{n}_{j}$ is the average annual density (numbers $/ \mathrm{m}^{2}$ ) of animals in size category $j$, all $e_{j}$ terms are equal to $l / i, a_{j}$ is the actual proportion of the life span spent in size category $\mathrm{j}$, and CPI is the life span (yr) as defined by the time from release from a brood to death in the largest size category. By substituting $1 / i$ for $e_{j}$, equation (1) may be rewritten:

$\mathbf{N}_{\mathrm{j}}=\overline{\mathrm{n}}_{\mathrm{j}} / \mathrm{D}_{\mathrm{j}}$

where $D_{j}=a_{j} C P I$, the development time (yr) spent in size category $\mathrm{j}$. The hypothetical relationship between total body length and age shown in Fig. 1, derived from Reynolds \& DeGraeve's (1972) and Morgan \& Beeton's (1978) characterization of $1 \mathrm{~mm} /$ month average growth rates for Mysis relicta in the Great Lakes, was used to estimate $D_{j}$. Use of a single length-age relationship compensates for differences among studies in the definition of size classes and assumes that growth is the same at all study sites. Further consequences of assumptions about growth rates are discussed below. Losses between numbers of animals growing into size categories were then converted into biomass as an estimate of production, P (Menzie 1980):

$P=\sum_{j=1}^{i}\left(N_{j}-N_{j+1}\right) \quad\left(W_{j} W_{j+1}\right)^{1 / 2}$

where $W_{j}$ is the mean weight of an individual in size category j. Krueger \& Martin (1980) suggest the use of geometric mean weights of size category average weights, $\left(\mathrm{W}_{\mathrm{j}} \mathrm{W}_{\mathrm{j}+1}\right)^{1 / 2}$, to estimate the weights of individuals lost.

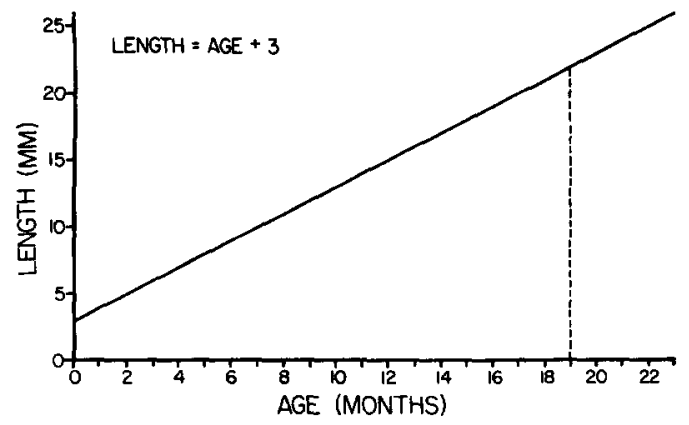

Fig. l. Hypothetical relationship between total body length (in $\mathrm{mm}$ ) and age (in months) used in production calculations to estimate the time spent in size categories. Of the five Great Lakes studies, only Reynolds \& DeGraeve (1972) observed mysids larger than $22 \mathrm{~mm}$, corresponding here to an age of 19 months (dotted line). 
Table 1. Summary of sampling methodology used in five Great Lakes studies of Mysis relicta. This summary represents the restricted subsets of data from the original studies which were used to calculate production estimates. Studies are arranged in approximate order by station depths examined.

\begin{tabular}{|c|c|c|c|c|c|}
\hline & Grossnickle & $\begin{array}{l}\text { Reynolds \& } \\
\text { DeGraeve }\end{array}$ & Beeton & Morgan & $\begin{array}{l}\text { Carpenter } \\
\text { et al. }\end{array}$ \\
\hline $\begin{array}{l}\text { Sampling } \\
\text { years }\end{array}$ & $\begin{array}{r}1975- \\
1976\end{array}$ & $\begin{array}{r}1970- \\
1971\end{array}$ & 1954 & $\begin{array}{r}1975- \\
1976\end{array}$ & 1971 \\
\hline No. dates & 17 & 10 & 6 & 11 & 7 \\
\hline Lake & Mich. & Mich. & Mich. & Mich. & Huron \\
\hline $\begin{array}{l}\text { Station } \\
\quad \text { depth (m) }\end{array}$ & 50 & $\begin{array}{l}45- \\
73\end{array}$ & 74 & 115 & ${ }_{210}^{90-}$ \\
\hline Gear & $\begin{array}{l}\text { Vert. } \\
\text { Haul }\end{array}$ & Sled & $\begin{array}{l}\text { C-B } \\
\text { Horiz. }\end{array}$ & $\begin{array}{l}\text { Sled } \\
\text { (flowmeter) }^{a}\end{array}$ & $\begin{array}{l}\text { Vert. } \\
\text { Haul }\end{array}$ \\
\hline Net mouth $\left(\mathrm{m}^{2}\right)$ & 0.44 & 1.0 & 0.02 & 1.0 & 1.0 \\
\hline Net mesh (mm) & 0.570 & 0.656 & 0.366 & 0.570 & 0.505 \\
\hline $\begin{array}{l}\text { Sampling } \\
\text { time }\end{array}$ & Night & Day & Night & Day & $\begin{array}{l}\text { Night } \\
\text { (\& day) }\end{array}$ \\
\hline $\begin{array}{c}\text { No. animals } \\
\text { measured }\end{array}$ & $6200^{b}$ & 4500 & 2850 & 1350 & 7300 \\
\hline $\begin{array}{l}\text { Measurement } \\
\text { used }\end{array}$ & $\mathrm{TBL}^{\mathrm{c}}$ & $\mathrm{TBL}^{\mathrm{c}}$ & $\mathrm{ASL}^{\mathrm{d}}$ & $\mathrm{BL}^{\mathrm{e}}$ & $\mathrm{TBL}^{\mathrm{c}}$ \\
\hline
\end{tabular}

\footnotetext{
Flow meter used at surface in conjunction with sled tows.

b Measured in the present study.

c Total body length - distance from tip of rostrum to tips of telson.

d Antennal scale length.

e Body length - distance from tip of rostrum to cleft of telson
}

Sampling times, depths, and collecting methods used in the five studies are summarized in Table 1. Details of the original methodology and restrictions imposed upon the data in the present study follow.

\section{Beeton's 1954 data}

Dr. A. M. Beeton provided unpublished size data from his study of the vertical migration of $M$. relicta (Beeton 1960). The data used here were collected in 1954 on six sampling dates from a $74 \mathrm{~m}$ depth station (Station 13) in Lake Michigan using horizontal tows of a calibrated Clarke-Bumpus sampler at 10 $\mathrm{m}$ depth intervals from 10 to $40 \mathrm{~m}$. Although series of tows were made at several times on each sampling date, only the two series of Clarke-Bumpus tows preceding midnight were used here as this was the time mysids were highest in the water column and available to the sampler. The volumetric estimates (numbers $/ \mathrm{m}^{3}$ ) of mysid densities obtained from the Clarke-Bumpus samples were converted into areal densities (numbers $/ \mathrm{m}^{2}$ ) by a simple integration of depth strata. Volumetric densities of mysids in surface, $10,20,30$, and $40 \mathrm{~m}$ tows were assumed to be representative of the water column intervals $0-5,5-15,15-25,25-35$, and $35-74 \mathrm{~m}$, respectively. All animals in a tow (except five tows which were sub-sampled) were measured by Beeton for antennal scale length to the nearest $0.125 \mathrm{~mm}$. Grossnickle \& Beeton (1979) have shown antennal scale length to be linearly related to total body length. In order to apply the size-frequency method I converted antennal scale length size classes into total body length size classes using a relation derived from Grossnickle \& Beeton (1979):

Total body length $(\mathrm{mm})=6.18$ [antennal scale length $(\mathrm{mm})]+0.50$.

\section{Reynolds \& DeGraeve's 1970-7I data}

Reynolds \& DeGraeve (1972) presented density and size class data obtained on 10 dates during 1970-1971 at station depths of 9-73 m. The data used here were restricted to collections from 45 to $73 \mathrm{~m}$ depths as little size-frequency information was available from shallower stations. 


\section{Watson's 1971 data}

Dr. N. H. F. Watson provided unpublished size category data from the study of Mysis relicta in Lake Huron reported by Carpenter et al. (1974). Approximately 33 stations were sampled on eight synoptic cruises between April and December 1971. Stations were visited on a predetermined path and samples collected day or night. Production estimates were derived only from stations $>90 \mathrm{~m}$ in depth as little size-frequency data were available from shallower stations. Furthermore, data from station depths of $90-130 \mathrm{~m}$ were used only if sampling was conducted at night. For station depths $>130 \mathrm{~m}$, data were used regardless of sampling time. The few deep stations sampled at night during April provided inadequate size-frequency information so only data from the other seven cruises were used in production calculations.

\section{Morgan's 1975-76 data}

Morgan (1976) presents data collected between August 1975 and July 1976 at a $115 \mathrm{~m}$ station northeast of Milwaukee in Lake Michigan. Dr. M. D. Morgan provided unpublished size category data derived from approximately 100 mysids from each sampling date. Morgan pooled replicate samples and measured a subsample of animals to the nearest $0.5 \mathrm{~mm}$ from the tip of the rostrum to the apical cleft of the telson. Since this body length measure differs from that used in other studies, Morgan's (1976) lengths were converted into weight using Morgan's (1976) relationship:

Dry weight $(\mathrm{mg})=0.00016$ (Length in $\mathrm{mm})^{3.94}$.

\section{Grossnickle's 1975-76 data}

Dr. N. E. Grossnickle and the Center for Great Lakes Studies of the University of Wisconsin-Milwaukee allowed the examination of an extensive series of samples collected with vertical net hauls of a $0.75-\mathrm{m}$ diam., $0.570-\mathrm{mm}$ plankton net. Three to five replicate samples were taken at a $50-\mathrm{m}$ station off Milwaukee on 17 sampling dates between June 1975 and May 1976. Total mysid density estimates from 15 of these dates were reported by Grossnickle \& Morgan (1979), but no size measurements were made. I measured total body length to the nearest millimeter for all specimens in at least two samples from each date.

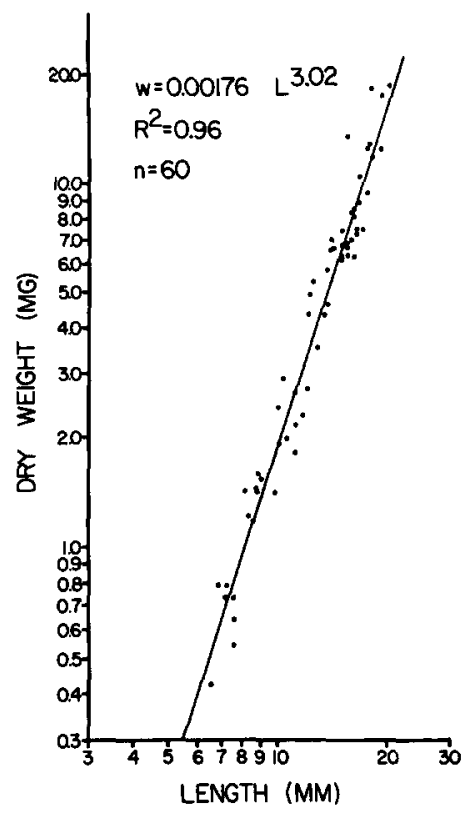

Fig. 2. Logarithm of dry weight (in $\mathrm{mg}$ ) versus logarithm of total body length (in $\mathrm{mm}$ ) for 60 Lake Michigan Mysis relicta specimens. The least squares regression line and equation are indicated.

NUMBERS
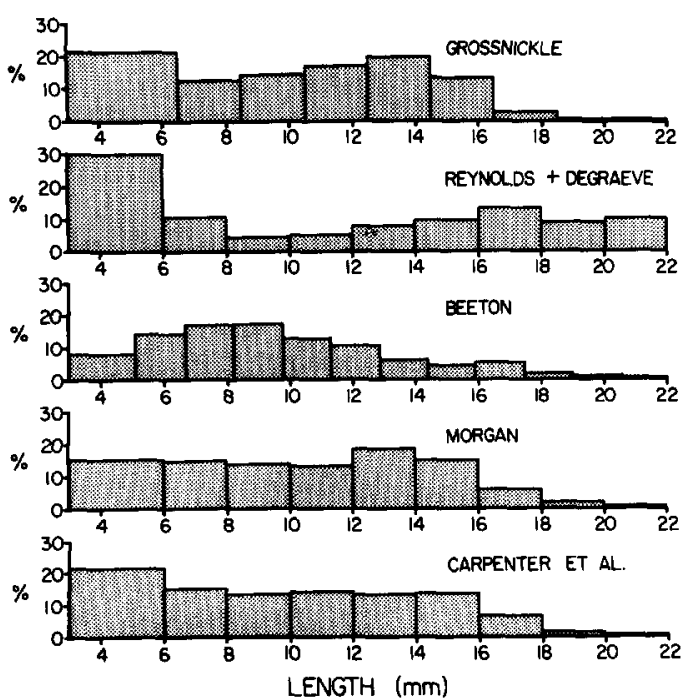

Fig. 3. Size-frequency plots of the total numbers of $M$ ysis relicta estimated to grow into total body length (in $\mathrm{mm}$ ) size categories for five Great Lakes studies. Note that the smallest size class spans a wider range of sizes than others and size categories differ between studies. Reynolds \& DeGraeve's (1972) data for animals $>22 \mathrm{~mm}$ lengths are included in the $\mathbf{2 0}-22 \mathrm{~mm}$ size category for the purpose of presentation. 


\section{Results}

A least-squares fit to logarithmically transformed length-weight data is shown in Fig. 2. The fitted exponent has a value close to 3 .

Size-frequency plots for the estimated numbers of animals growing into size categories $\left(\mathrm{N}_{\mathrm{j}}\right)$ are shown in Fig. 3 for all five Great Lakes investigations. In contrast to the other studies, estimates from Reynolds \& DeGraeve's (1972) study indicate a large fraction of animals observed were in $>16 \mathrm{~mm}$ size categories. The size-frequency plot for Beeton's data peaked in the 8.2-9.8 mm size category despite the wider range in lengths spanned by the smallest size class. This suggests that numbers of animals growing into the two smallest size categories may have been underestimated either in the original sampling or as a result of growth rate assumptions in the calulations.

Histograms of average annual standing crop for body length size categories are shown in Fig. 4. Highest fractions of average biomass occurred in size classes $>14 \mathrm{~mm}$ for all five studies. In contrast to the other studies, average biomass was highest in the 20-22 mm size category for Reynolds \& Degraeve's (1972) data. Total standing crop versus month of sampling is shown in Fig. 5. Of the three studies having nearly year-round sampling, standing crop reached lowest values during NovemberFebruary. However, the large date-to-date variations in biomass estimates prevents more detailed conclusions. The ratios of maximum to minimum biomass values within a year were 15, 519,9,17 and 3 for the data of Grossnickle, Reynolds and DeGraeve, Beeton, Morgan and Carpenter et al., respectively.

Annual secondary production, average annual biomass $(\overline{\mathrm{B}})$, mean annual density $(\overline{\mathrm{D}})$, and $\mathrm{P}: \overline{\mathrm{B}}$ ratio estimates are given in Table 2 . $P, \overline{\mathbf{B}}$ and $\mathbf{P}: \overline{\mathrm{B}}$ estimates in Table 2 were calculated for the size categories, which span approximately $2.0 \mathrm{~mm}$ length classes, shown in Figs. 3 and 4. These estimates are altered by $<2 \%$ if size categories are based on the original measurement classes, which generally spanned 0.5 or $1.0 \mathrm{~mm}$ length ranges. Lowest values of $P, \bar{B}$ and $D$ were obtained for Reynolds \& DeGraeve's (1972) study and highest values were calculated from Grossnickle's data. Although these estimates differ by an order of magnitude, $\mathrm{P}: \overline{\mathrm{B}}$ ratios differed by less than $50 \%$.
STANDING CROP

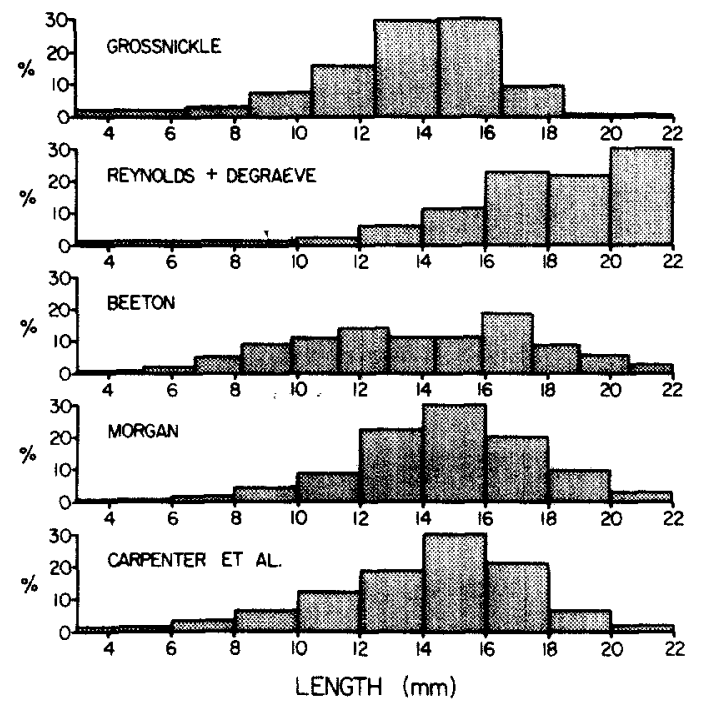

Fig. 4. Size-frequency plots of the average annual biomass present in total body length (in $\mathrm{mm}$ ) size classes for Mysis relicta populations described in five Great Lakes studies. Note that the smallest size class spans a wider range of sizes than others and size categories differ between studies. Reynolds \& DeGraeve's (1972) data for animals $>22 \mathrm{~mm}$ lengths are included in the 20-22 mm size category for the purpose of presentation.

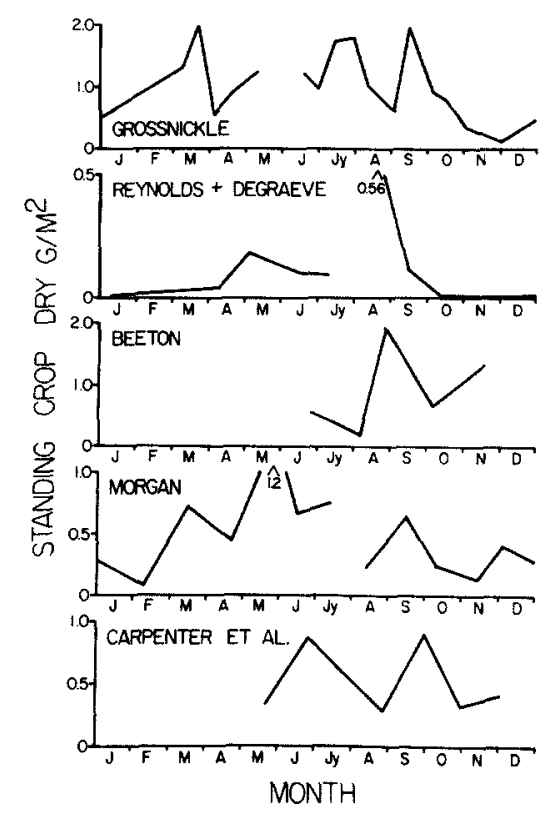

Fig. 5. Standing crop (in dry $\mathrm{g} / \mathrm{m}^{2}$ ) versus month of sampling for five Great Lakes studies. Biomass estimates are derived from length-weight regressions and length data. Note the different vertical scales used. 
Table 2. Estimates of secondary production $(\mathrm{P})$, average annual biomass $(\overline{\mathrm{B}})$, mean annual density $(\overline{\mathrm{D}})$ and $\mathrm{P}: \overline{\mathrm{B}}$ ratios for five Great Lakes studies of Mysis relicta populations.

\begin{tabular}{llllll} 
& Grossnickle & $\begin{array}{l}\text { Reynolds \& } \\
\text { DeGraeve }\end{array}$ & Beeton & Morgan & $\begin{array}{l}\text { Carpenter } \\
\text { et al. }\end{array}$ \\
\hline $\mathrm{P}\left(\mathrm{dry} \mathrm{g} \mathrm{m}^{-2} \mathrm{yr}^{-1}\right)$ & 3.2. & 0.25 & 2.5 & 1.7 & 1.5 \\
$\overline{\mathrm{B}}\left(\mathrm{dry} \mathrm{g} \mathrm{m} \mathrm{g} \mathrm{m}^{-2}\right)$ & 1.11 & 0.11 & 0.85 & 0.52 & 0.53 \\
$\mathrm{D}\left(\mathrm{No}^{-2}\right)$ & 434 & 25 & 349 & 171 & 204 \\
$\mathrm{P}: \overline{\mathrm{B}}\left(\mathrm{yr}^{-1}\right)$ & 2.9 & 2.2 & 2.9 & 3.3 & 2.8 \\
\hline
\end{tabular}

\section{Discussion}

Despite the original intent of the size-frequency method's proponents, Waters (1977) cites only one instance in which the size-frequency method has been used to calculate production of an aggregate of species. Apparently, few investigators have chosen to work with species aggregates because many assumptions are necessary. When the size-frequency model is applied to a single species the assumptions are less severe: 1) animals spend a known amount of time in each size class; 2) sampling times are equally spaced throughout a year; 3 ) all sizes of animals are sampled quantitatively. Hamilton (1969) and Cushman et al. (1978) have used simulations to examine the robustness of the method to departures from the first two assumptions.

Assuming overall life span is accurately defined, both studies conclude that errors due to violations of assumptions 1 and 2 are minor compared to sampling errors associated with density estimates. In their analysis of approximate confidence intervals for size-frequency production estimates, Krueger \& Martin (1980) identify the number of sampling dates as having an important influence on the variability of the production estimator. Waters \& Crawford (1973) and Cushman et al. (1978) have compared the size-frequency method to other methods under circumstances in which cohorts can be followed and conclude that size-frequency production estimates are quite accurate when applied to single species.

Differences in the estimates of Mysis relicta standing stocks may be largely attributed to differences in sampling location, particularly station depth, as well as differences in sampling gear and year-to-year variations in abundance. Robertson $e t$ al. (1968) observed that mysid abundance increased with depth for six Lake Michigan stations ranging in depth from 17 to $262 \mathrm{~m}$. Reynolds \& Degraeve
(1972) reported increasing mysid densities (numbers $/ \mathrm{m}^{2}$ ) with depth to $150 \mathrm{~m}$ in lake Michigan. Carpenter et al. (1974) found that mysid densities increased with depth up to depths of $200 \mathrm{~m}$ in Lakes Huron, Ontario, and Superior. McWilliam (1970) reported that over a four year period densities determined from vertical hauls were more than three times greater at a $270 \mathrm{~m}$ station in Lake Michigan than at a $150 \mathrm{~m}$ station. Because of the direct relationship of mysid abundance to depth demonstrated by these studies, it is expected that mysid production would also show a strong relationship to depth. This expectation is not substantiated by the calculations presented here, apparently because of differences in sampling techniques between studies. However, production estimates (McWilliam \& Sell, unpublished) drawn from density data reported by McWilliam (1970) indicate secondary production by $M y$ sis relicta at a $270-\mathrm{m}$ station in Lake Michigan exceeds the maximum value reported here by a factor of 2.

Grossnickle \& Morgan (1979) compared sampling methods for collecting $M$. relict $a$ and concluded that daytime vertical net hauls severely underestimated mysid densities. They also found that late instar mysids made up a significantly larger percentage of sled catches than catches from vertical tows at a $115-\mathrm{m}$ station in Lake Michigan. Although Beeton's samples were taken at night, the bottom $30 \mathrm{~m}$ of the water column was not sampled. Thus, larger mysids, which tend not to migrate as high into the water column as small mysids (Beeton 1960), may not have been well represented in Beeton's samples. Nevertheless, density and biomass estimates from Beeton's collections are almost as high as values from Grossnickle's samples. Two of the chief problems in using sleds are that the bottom area sampled can not be accurately measured (McWilliam 1970; Reynolds \& DeGraeve 1972; Morgan 1976) and that mysids may reside above 
bottom in deep waters even during the day (Robertson et al. 1968; Malley \& Reynolds 1979). The low estimates of $P, \bar{B}$, and $\bar{D}$ derived from Reynolds \& DeGraeve's (1972) study may represent a systematic bias resulting from sled sampling. The problem of quantifying sled data also may have contributed to the dramatic annual variation in biomass observed by Reynolds \& DeGraeve (1972).

Although a linear growth model was used in production calculations here, Clutter \& Theilacker's (1971) study suggests that an asymptotic growth curve is a reasonable characterization of growth under laboratory conditions for another mysid, Metamysidopsis elongata. Under natural conditions of varying temperature, pressure, and food availability, neither a simple asymptotic curve nor a linear relationship would be expected to apply strictly. McWilliam (1970) presents evidence that growth is slower in deep areas of Lake Michigan than in shallower regions. Reynolds \& Degraeve (1972) suggest that average growth of mysids in Lake Michigan is greater during January-April than during the rest of the year. Studies from other lakes (Lasenby \& Langford 1972; Hakala 1978; Morgan 1981) indicate that mysid populations may have seasonal changes in growth rate in which growth during winter is slower than in warmer seasons. In the absence of better information on growth rates of Mysis relicta in the Great Lakes, a simple linear growth model, such as the one used for calculating production estimates in the present study, is an appropriate approximation. Indeed, a linear growth curve would not appear to be distinguishable from the slightly S-shaped curve that Morgan \& Beeton (1978) fit by eye to Lake Michigan data. Furthermore, Hamilton (1969) and Cushman et al. (1978) concluded that size-frequency production estimates are affected relatively little by the use of linear versus curvilinear growth models. The overall rate of growth, and hence whether all $D_{j}$ estimates are systematically biased, deserves further study.

The length-weight relationship used here is similar to ones presented for Mysis relicta in Lake Tahoe (Morgan 1979) and in Stony Lake (Lasenby \& Langford 1972). However, more extensive examination of length-weight relationships for the smallest and largest size category animals would strengthen production calculations. Also, regression techniques other than least-squares may prove use- ful (Ricker 1973).

Another minor improvement is suggested by the work of Martien \& Benke (1977). Although Hamilton (1969) cautioned that negative production values for individual size categories must be included to avoid biasing the total production sum, Martien \& Benke (1977) argue that negative production values obtained from small size groups less susceptible to sampling gear should be ignored. This amounts to recognition that the assumption of no gear selectivity among size classes does not hold. This adjustment would increase the production estimate from Beeton's data by only 3.3.\%. Underestimates of densities of large mysids would be expected to have a more pronounced effect on production estimates because of their greater weight.

The only previous estimate of annual production by $M$. relicta in the Great Lakes is Morgan's (1976) estimate of $0.95 \mathrm{~g} \mathrm{~m}^{-2} \mathrm{yr}^{-1}$ (and $\mathrm{P}: \mathrm{B}^{-}=2.0$ ). This is a production value approximately half that calculated from Morgan's data using the size-frequency method. To obtain his estimate, Morgan used density estimates of newly released young in each of three spurts of reproduction occurring within a year and extrapolated a linear decline in numbers of each cohort up to an age of 16 months. Because his estimates of the peak density of young in a cohort were based on individual sampling times, Morgan cautioned that his annual production estimate might be low. Also, Morgan's production value should be considered an underestimate because reproduction occurring between the three major cohorts was ignored. The size-frequency estimates presented here have the advantage of utilizing density data for all sizes of animals on all sampling dates.

Annual production has been estimated using cohort discrimination methods for Mysis relicta in two lakes (Table 3). Although the standing stocks of $M$. relicta in Lake Pääjärvi are low compared to estimates for Lake Michigan, $\mathrm{P}: \mathrm{B}^{-}$ratios are comparable. The very low production in the main basin of Lake Tahoe is partially a result of a steady decline in the mysid population between 1975 and 1979 (Morgan 1979, 1980). However, low P : ${ }^{-}$ratios for main basin and Emerald Bay populations indicate the production dynamics of Mysis in Lake Tahoe differ considerably from those of populations in the Great Lakes and Lake Päajärvi. Ponto- 
Table 3. Estimates of secondary production (P), average annual biomass $(\overline{\mathrm{B}})$ and $\mathrm{P}: \mathrm{B}$ ratios derived using cohort discrimination techniques for studies of Mysis relicta and Pontoporeia hoyi populations.

\begin{tabular}{|c|c|c|c|}
\hline & \multicolumn{3}{|c|}{ Mysis relicta } \\
\hline & \multirow{2}{*}{$\begin{array}{l}\text { Hakala (1978) } \\
\text { Lake Pääjärvi }\end{array}$} & \multirow{2}{*}{\multicolumn{2}{|c|}{$\begin{array}{l}\text { Morgan (1979) } \\
\text { Emerald Bay }\end{array}$}} \\
\hline & & & \\
\hline$P\left(\right.$ dry $\left.g^{-2} \mathrm{yr}^{-1}\right)$ & $0.17-0.28$ & $0.06-0.20$ & $0.99-1.24$ \\
\hline $\mathrm{B}\left(\mathrm{dry} \mathrm{g} \mathrm{m}^{-2}\right)$ & $0.05-0.09$ & $0.12-0.30$ & $0.60-0.65$ \\
\hline $\mathbf{P}: \bar{B}\left(y^{-1}\right)$ & $3.0-3.8$ & $0.47-0.66$ & $1.6-1.9$ \\
\hline
\end{tabular}

Pontoporeia hoyi

\begin{tabular}{lll} 
& $\begin{array}{l}\text { Lubner }(1974) \\
\text { Lake Michigan }(140 \mathrm{~m})\end{array}$ & $\begin{array}{l}\text { Lubner (1979) } \\
\text { Lake Michigan }(65-115 \mathrm{~m})\end{array}$ \\
\hline $\mathrm{P}\left(\right.$ dry g m$^{-2} \mathrm{yr}^{-1}$ & $0.8-1.3$ & $2.9-6.0$ \\
$\left.\mathrm{~B}(\mathrm{dry} \mathrm{g} \mathrm{m})^{-2}\right)$ & 1.95 & $2.56-5.24$ \\
$\mathrm{P}: \overline{\mathrm{B}}\left(\mathrm{yr}^{-1}\right)$ & $0.41-0.67$ & $1.09-1.14$ \\
\hline
\end{tabular}

poreia hoyi is the only large and abundant crustacean in the Great Lakes for which production is comparable to that of Mysis (Table 3). Lubner's (1974, 1979) examinations of $P$. hoyi populations substantiate Cook \& Johnson's (1974) suggestion that production by benthic communities may range as high as $5.0 \mathrm{~g} \mathrm{~m}^{-2} \mathrm{yr}^{-1}$ in offshore regions of Lake Michigan.

In conclusion, Grossnickle's data represent the most complete information a vailable for Mysis relicta populations at a single location in the Great Lakes due to the high sampling frequency and the collection efficiency of night-time vertical hauls. Although the production estimates derived from Grossnickle's data set are the best presently available for the Great Lakes, these estimates should be considered conservative for populations at depths greater than $50 \mathrm{~m}$. Beyond problems in the frequency and bias of sampling, future refinements of production estimates for Great Lakes mysid populations will require more precise information on growth rates.

\section{Acknowledgments}

This research was sponsored by Michigan Sea Grant under grants from the Office of Sea Grant, NOAA, U.S. Department of Commerce and funds from the State of Michigan. The U.S. government is authorized to produce and distribute reprints for governmental purpose notwithstanding any copyright notation that may appear. Computer funds were supplied by the University of Michigan School of Natural Resources. This study would not have been possible without unpublished data and original samples kindly provided by Drs. A. M. Beeton, N. E. Grossnickle, M. D. Morgan and N. H. F. Watson. I thank Dr. Beeton for encouraging this study and Dr. J. A. Bowers for helpful criticism.

\section{References}

Beeton, A. M., 1960. The vertical migration of Mysis relicta in Lakes Huron and Michigan. J. Fish. Res. Bd Can. 17: 517-539.

Benke, A. C., 1976. Dragonfly production and prey turnover. Ecology 57: 915-927.

Benke, A. C., 1979. A modification of the Hynes method for estimating secondary production with particular significance for multivoltine populations. Limnol. Oceanogr. 24: 168 -171 .

Bowers, J. A. \& Grossnickle, N. E., 1978. The herbivorous habits of Mysis relicta in Lake Michigan. Limnol. Oceanogr. 23: 767-776.

Carpenter, G. F., Mansey, E. L. \& Watson, N. H. F., 1974. Abundance and life history of Mysis relicta in the St. Lawrence Great Lakes. J. Fish. Res. Bd Can. 31: 319-325.

Clutter, R. I. \& Theilacker, G. H., 1971. Ecological efficiency of a pelagic mysid shrimp; estimates from growth, energy budget, and mortality studies. Fishery Bull. 69: 93-115.

Cook, D. G. \& Johnson, M. G., 1974. Benthic macroinvertebrates of the St. Lawrence Great Lakes. J. Fish. Res. Bd Can. 31: 763-782.

Cooper, S. D. \& Goldman, C. R., 1980. Opossum shrimp (Mysis relicta) predation on zooplankton. Can. J. Fish- aquat. Sci. 37: 909-919.

Cushman, R. M., Shugart, H. H. Jr., Hildebrand, S. G. \& Elwood, J. W., 1978. The effect of growth curve and sam- 
pling regime on instantaneous-growth, removal-summation, and Hynes/Hamilton estimates of aquatic insect production: a computer simulation. Limnol. Oceanogr. 23: 184189.

Eckblad, J. W., 1973. Population studies of three aquatic gastropods in an intermittent backwater. Hydrobiologia 4l: 199 219 .

Ferrante, J. G. \& Parker, J. I., 1978. The influence of planktonic and benthic crustaceans on silicon cycling in Lake Michigan, U.S.A. Verh. int. Verein. Limnol. 20: 324-328.

Foltz, J. W. \& Norden, C. R., 1977. Food habits and feeding chronology of rainbow smelt, Osmerus mordax in Lake Michigan. Fishery Bull. 75: 637-640.

Goldman, C. R., Morgan, M. D., Threlkeld, S. T.\& Angeli, N., 1979. A population dynamics analysis of the cladoceran disappearance from Lake Tahoe, California-Nevada. Limnol. Oceanogr. 24: 289-297.

Grossnickle, N. E., 1978. The herbivorous and predaceous habits of Mysis relicta in Lake Michigan. Ph. D. thesis, Univ. of Wisconsin-Madison. $107 \mathrm{pp}$.

Grossnickle, N. E., 1979. Nocturnal feeding patterns of Mysis relicta in Lake Michigan, based on gut content fluorescence. Limnol. Oceanogr. 24: 777-780.

Grossnickle, N. E.\& Beeton, A. M., 1979. Antennal scale length as a measure of relative size in the opossum shrimp, Mysis relicta Loven. Crustaceana 36: 141-146.

Grossnickle, N. E. \& Morgan, M. D., 1979. Density estimates of Mysis relicta in Lake Michigan. J. Fish. Res. Bd Can. 36: 694-698.

Hakala, I, 1978. Distribution, population dynamics and production of Mysis relicta (Loven) in southern Finland. Ann. zool. fenn. 15: 243-258.

Hamilton, A. L., 1969. On estimating annual production. Limnol. Oceanogr. 14: 771-782.

Hynes, H. B. N., 1980. A name change in the secondary production business. Limnol. Oceanogr. 25: 778.

Hynes, H. B. N. \& Coleman, M. H., 1968. A simple method of assessing the annual production of stream benthos. Limnol. Oceanogr. 13: 569-573.

Janssen, J. \& Brandt, S. B., 1980. Feeding ecology and vertical migration of adult alewives (Alosa pseudoharengus) in Lake Michigan. Can. J. Fish. aquat. Sci. 37: 177-184.

Krueger, C. C. \& Martin, F. B., 1980. Computation of confidence intervals for the size frequency (Hynes) method of estimating secondary production. Limnol. Oceanogr. 25: 773-777.

Lasenby, D. C. \& Langford, R. R., 1972. Growth, life history and respiration of $M y$ sis relicta in an aretic and temperate lake. J. Fish. Res. Bd Can. 29: 1701-1708.

Lubner, J. F., 1974. Dynamics and net secondary production of a population of Pontoporeia affinis at a deep-water Lake Michigan station. M.S. thesis, Univ. of Wisconsin-Milwaukee. 41 pp.

Lubner, J. F., 1979. Population dynamics and production of the relict amphipod Pontoporeia hoyi, at several Lake Michigan stations. Ph. D. thesis, Univ. of Wisconsin-Milwaukee. 98 pp.

Malley, D. F. \& Reynolds, J. B., 1979. Sampling strategies and life history of non-insectan freshwater invertebrates. J. Fish. Res. Bd Can. 36: 311-318.
Martien, R. F. \& Benke, A. C., 1977. Distribution and production of two crustaceans in a wetland pond. Am. Midl. Nat. 98: $162-175$.

McWilliam, P. S., 1970. Seasonal changes in abundance and reproduction in the 'opossum shrimp', Mysis relicta Loven, in Lake Michigan. M.S. thesis. Univ. of Sydney. $94 \mathrm{pp}$.

Menzie, C. A., 1980. A note on the Hynes method of estimating secondary production. Limnol. Oceanogr. 25: 770-773.

Morgan, M. D., 1976. Life history and annual net secondary productivity of Mysis relicta (Loven) in westcentral Lake Michigan. M.S. thesis, Univ. of Wisconsin-Milwaukee. $55 \mathrm{pp}$.

Morgan, M. D., 1979. The dynamics of an introduced population of Mysis relicta (Loven) in Emerald Bay and Lake Tahoe Davis. 101 pp.

Morgan, M. D., 1980. Life history characteristics of two introduced populations of Mysis relicta. Ecology 61: 551-561.

Morgan, M. D., 1981. Abundance, life history, and growth of introduced populations of the opossum shrimp (Mysis relicta) in subalpine California lakes. Can. J. Fish. aquat. Sci. 38: 989-993.

Morgan, M. D. \& Beeton, A. M., 1978. Life history and abundance of Mysis relicta in lake Michigan. J. Fish. Res. Bd. Can. 35: 1165-1170.

Morgan, M. D., Threlkeld, S. T. \& Goldman, C. R., 1978. Impact of the introduction of kokanee (Orcorhynchus nerka) and opossum shrimp (Mysis relicta) on a subalpine lake. J. Fish. Res. Bd Can. 35: 1572-1579.

Morsell, J. W. \& Norden, C. R., 1968. Food habits of the alewife, Alosa pseudoharengus (Wilson) in Lake Michigan. In: Proc. 11th Conf. Great Lakes Res., pp. 96-102. Int. Assoc. Great Lakes Res.

Northcote, T. G., 1972. Some effects of mysid introductions and nutrient enrichment on a large oligotrophic lake and its salmonids. Verh. int. Verein. Limnol. 18: 1096-1106.

Parker, J. I., 1980. Predation by Mysis relicta on Pontoporeia hoyi: a food chain link of potential importance in the Great Lakes. J. Great Lakes Res. 6: 164-166.

Reynolds, J. B. \& DeGraeve, G. M., 1972. Seasonal population characteristics of the opossum shrimp, Mysis relicta, in southeastern Lake Michigan, 1970-1971. In: Proc. 15th Conf. Great Lakes Res., pp. 117-131. Int. Assoc. Great Lakes Res.

Richards, R. C., Goldman, C. R., Frantz, T. C.\& Wickwire, R., 1975. Where have all the Daphnia gone? The decline of a major cladoceran in Lake Tahoe, California-Nevada. Verh. int. Verein. Limnol. 19: 835-842.

Ricker, W. E., 1973. Linear regressions in fisheries research. J. Fish. res. Bd. Can. 30: 409-434.

Robertson, A., Powers, C. F. \& Anderson, R. F., 1968. Direct observations of Mysis relicta from a submarine. Limnol. Oceanogr. 13: 700-702.

Waters, T. F., 1977. Secondary production in inland waters. Adv. Ecol. Res. 10: 91-164.

Waters, T. F.\& Crawford, G. W., 1973. Annual production of a stream mayfly population: a comparison of methods. Limnol. Oceanogr. 19: 286-296.

Waters, T. F. \& Hokenstrom, J. C., 1980. Annual production and drift of the stream amphipod Gammarus pseudolimnaeus in Valley Creek, Minnesota. Limnol. Oceanogr. 25: $700-710$ 
Wells, L. \& Beeton, A. M., 1963. Food of the bloater, Coregonus hoyi, in Lake Michigan. Trans. Am. Fish. Soc. 92: 245-255. Welton, J. S., 1979. Life history and production of the amphipod Gammarus pulex in a Dorset chalk stream. Freshwat. Biol. 9: 263-275.
Zyblut, E. R., 1970. Long-term changes in the limnology and macrozooplankton of a large British Columbia lake. J. Fish. Res. Bd Can. 27: 1239-1250. 